
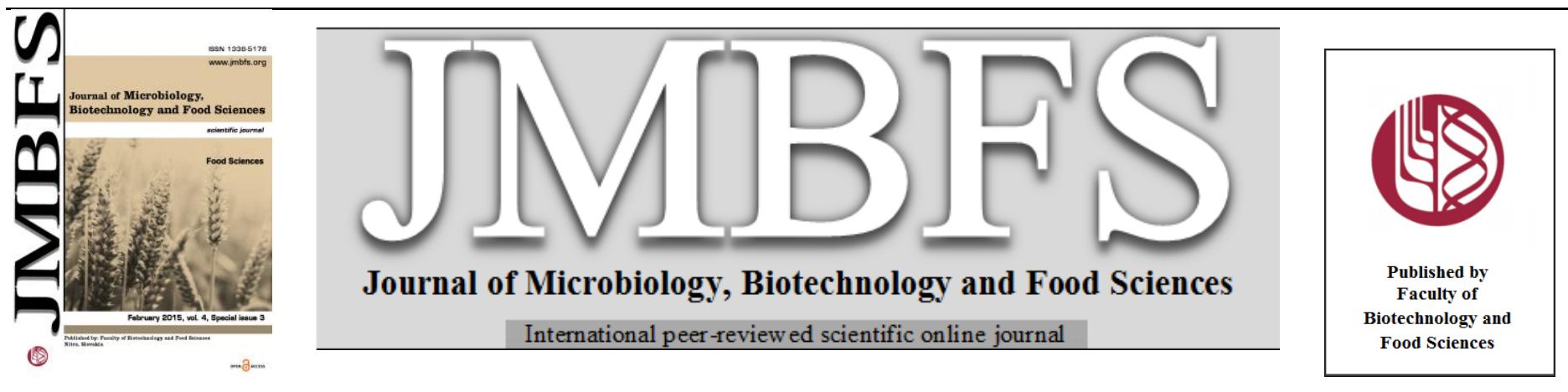

\title{
ATTEMPT TO APPLY STABILIZED WHEAT GERM FOR BREAD SUPPLEMENTATION
}

\section{Halina Gambus ${ }^{1}$, Florian Gambuś $^{2}$, Gabriela Zięć ${ }^{1}$, Dorota Litwinek ${ }^{1}$, Barbara Mickowska ${ }^{3}$, Renata Sabat ${ }^{1}$, Wiktor Berski ${ }^{1}$}

\author{
Address(es): Professor Halina Gambuś, PhD. \\ ${ }^{1}$ University of Agriculture in Krakow, Faculty of Food Technology, Department of Carbohydrate Technology, Balicka Street $122,30-149$ Krakow phone number: +48 \\ 126624747. \\ ${ }^{2}$ University of Agriculture in Krakow, Faculty of Agriculture and Economics, Department of Agricultural and Environmental Chemistry, Mickiewicza Street 21, 31- \\ 120 Krakow. \\ ${ }^{3}$ University of Agriculture in Krakow, Faculty of Food Technology, Malopolska Centre for Monitoring and Certification of Food, Balicka 122, 30-149 Krakow.
}

*Corresponding author:rrhgambu@cyf-kr.edu.pl

doi: 10.15414/jmbfs.2015.4.special3.40-43

\section{ARTICLE INFO}

Received 20.11. 2014

Revised 3. 12. 2014

Accepted 4. 12. 2014

Published 2. 2. 2015

Regular article

open $\bigodot_{\text {access }}$

\section{ABSTRACT}

The increased interest in rational nutrition causes, that from many years is observed a growing consumption of bread, and novel food supplemented with health promoting components. For the bread production in Poland mainly wheat and rye cake flours are used, depleted of a many valuable nutrients such as protein, dietary fibre, minerals and vitamins. Because of their unique chemical composition wheat germs are a particularly valuable resource, both for direct consumption and to enhance the nutritional value of food products. The aim of the study was to prepare wheat bread with a $10 \%$ addition of commercial stabilized wheat germs. Based on the obtained results, it was found that wheat germs, due to their unique chemical composition, were a particularly valuable resource to supplement the nutritional value of bread. However, germs had detrimental effect on mechanical properties of dough, and on bread quality. Texture of bread crumb and its chemical composition were analysed. It was shown, that germs subjected to fermentation process could be used in wheat bread production as dietary fibre and mineral compound supplement.

Keywords: Stabilized wheat germs, wheat bread, leaven, chemical composition

\section{INTRODUCTION}

The increased interest in rational nutrition causes, that from many years is observed a growing consumption of bread, and novel food supplemented with health promoting components. For the bread production in Poland mainly wheat and rye cake flours are used, depleted of a many valuable nutrients such as protein, dietary fibre, minerals and vitamins. Because of their unique chemical composition wheat germs are a particularly valuable resource, both for direct consumption and to enhance the nutritional value of food products (Marciniak and Obuchowski, 2007; Kawka, 2009 a).

Wheat germs are a natural, valuable vitamin and protein concentrate, with a high antioxidant activity. They are characterized by extremely elevated level (approximately 25\%) of a protein with a high biological value, lipids (approximately $10 \%$ ) including mainly polyene EFA, minerals $\mathrm{Ca}, \mathrm{Mg}, \mathrm{Zn}$ and $\mathrm{P}$ (approximately $4.2 \%$ ) and about $20 \%$ of dietary fibre. They are a rich source of B vitamins (five to six times richer in vitamin $\mathrm{B}_{1}$ than wheat grains, about 25 -fold than wheat flour), vitamin E, tocopherols and sterols, which play an essential role in rational human nutrition, as well as have beneficial effect on lowering blood cholesterol level (Gąsiorowski, 2004 a; Kawka, 2009 a). The biological value of wheat germs protein is similar to the animal ones. They are devoid of gluten protein. Their fractional composition of proteins is completely different from the proteins of whole wheat grain: albumin constitutes over $30 \%$, globulin - about $19 \%$, prolamine (gliadin) approximately $14 \%$ and approximately $0.4 \%$ glutenin. Insoluble proteins constitute for approximately 30\% (Gasiorowski, 2004 b).

In the mid-fifties of the twentieth century in Poland germs began to make a career in dietetics, due to the their extremely valuable nutritional value, mainly as a food additive in hospitals for children and convalescents.

Studies conducted at that time revealed also the detrimental effect of germs on physical and mechanical properties of dough, and resulting bread quality. The introduction of germs caused reduction of flour water absorption capacity, rapid cake melting, reduction of bread_volume, and crumb darkening. This multilateral adverse effect on flour, cakes and breads properties limited the amount of germs introduced to the dough, and demanded a specific germs preparation, or to add an appropriate technological additives or to introduce some process modifications. This adverse effect was attributed to the presence of high level of glutathione in wheat germs (Gąsiorowski, 2005 ).
Method of mixed bread production with a $10 \%$ share of wheat germs was proposed by Jankowski (1981) in the 50's of the last century, and the resulting bread was available on the market as "Wielkopolski bread " (Gasiorowski, 2005; Kawka, 2009 b).

Since that time not many studies were conducted in Poland on the possible application of wheat germs in bakery. Currently most of the germs on the market is sold as stabilized, intended for direct consumption, and they do not receive recognition neither by consumers nor by producers.

Therefore the aim of this study was to prepare wheat bread with a $10 \%$ share of stabilized wheat germs.

\section{MATERIAL AND METHODS}

Wheat flour type 650 (PZZ Kraków S.A.), instant yeast (Lesaffre) and commercial stabilized wheat germs (Sante) were used in bread making.

Analyzes were conducted on standard wheat bread (no germs addition), wheat bread with $10 \%$ share of germs, wheat bread with a $10 \%$ share of roasted germs, and wheat bread with $10 \%$ share of germs in the form of leaven.

The measurement of water absorption of wheat flour and mixtures of wheat flour containing $10 \%$ of germs (calculated on the weight of the flour) was performed in a Brabender Farinograph E according to ICC standard - No 115/1, to obtain a standard dough consistency of $500 \mathrm{BU}$ Using the established values, the amount of water needed to obtain a dough with consistency of $350 \mathrm{BU}$ was calculated.

Leaven was prepared from $100 \mathrm{~g}$ of stabilized wheat germs, $364 \mathrm{~cm}^{3}$ of water, 30 $\mathrm{g}$ of yeast and $10 \mathrm{~g}$ of sugar. Fermentation was carried out at $30^{\circ} \mathrm{C}$ in the fermentation chamber of baking oven for $24 \mathrm{~h}$

According to recipes in Table 1 such dough (consistency of $350 \mathrm{BU}$ ) was prepared in a spiral dough mixer type Diosna 12 by direct or indirect (with the use of leaven) methods at various kneading time: $9 \mathrm{~min}$ for standard bread (3 min. at low hook speed, $6 \mathrm{~min}$. at high hook speed), $6 \mathrm{~min}$ for germs supplemented bread. ( $3 \mathrm{~min}$. at low hook speed, $3 \mathrm{~min}$. at high hook speed), and 6 min. (at high hook speed) for bread with germs addition in form of leaven. Mixing times and applied rotation speed of hooks were experimentally determined.

The first fermentation was carried out for $15 \mathrm{~min}$., followed by rounding a $250 \mathrm{~g}$ weight portion, next a final fermentation was carried out at the temperature of 
$40^{\circ} \mathrm{C}$ for $30 \mathrm{~min}$. fermentation chamber. Test breads were baked at $230^{\circ} \mathrm{C}$ for 30 min. in MIWE CONDO Co 2608 modular oven.

Table 1 Test wheat bread recipes with and without addition of stabilized wheat germs

\begin{tabular}{lllll}
\hline Raw material & Standard bread & $\begin{array}{l}\text { Bread with } \mathbf{1 0 \%} \text { share } \\
\text { of germs }\end{array}$ & $\begin{array}{l}\text { Bread with 10\% } \\
\text { of roasted germs }\end{array}$ & $\begin{array}{l}\text { Bread with 10\% share } \\
\text { of germs prepared as } \\
\text { leaven }\end{array}$ \\
\hline $\begin{array}{l}\text { Wheat flour type } 650 \\
{[\mathrm{~g}]}\end{array}$ & 1000 & 900 & 900 & 900 \\
\hline $\begin{array}{l}\text { Grounded germs } \\
{[\mathrm{g}]}\end{array}$ & - & 100 & $100^{*}$ & 100 \\
\hline $\begin{array}{l}\text { Yeast instant } \\
{[\mathrm{g}]}\end{array}$ & 30 & 30 & 30 & $-* *$ \\
\hline $\begin{array}{l}\text { Salt } \\
{[\mathrm{g}]}\end{array}$ & 15 & 15 & 15 & 15 \\
\hline $\begin{array}{l}\text { Water } \\
{\left[\mathrm{cm}^{3}\right]}\end{array}$ & 625 & 614 & 614 & 310 \\
\hline Germ leaven & - & - & - & as mentioned above \\
\hline $\begin{array}{l}\text { Dry wheat gluten } \\
{[\mathrm{g}]}\end{array}$ & - & - & - & 50 \\
\hline
\end{tabular}

*The germs were roasted at $230^{\circ} \mathrm{C}$ for $4 \mathrm{~min}$.
**The yeast were added to the slurry

Breads provided to analysis were freshly baked. After 2-hours cooling mass and loaf volume (in bulk material) were measured. Also sensory evaluation was carried out (PN-A-74108: 1996) by 15 persons evaluation panel of proven sensory sensitivity (Fortuna, 2012). Breads designed for storage were packed in HDPE film bags and stored at approximately $20^{\circ} \mathrm{C}$ for three successive days. The samples for the determination of the chemical composition were air dried at room temperature, and then grounded in a mill (Zelmer type 886.8). Also bread yield and baking loss were calculated (Jakubczyk and Haber, 1981).

The following analyses were performed on baking and the following 3-days (72h) of storage:

- $\quad$ Bread crumb moisture content 925.10, AOAC 2006;

- $\quad$ Texture profile analysis (TPA) of bread crumb using TA-TX2 PLUS texturometer (Stable Micro Systems). Tests were carried out using a $\mathrm{P}-20$ probe, moving at $5 \mathrm{~mm} / \mathrm{sec}$, measuring the strain in the layer of $10 \mathrm{~mm}$. The following TPA features were analyzed: crumb hardness expressed as the force required to achieve a deformation of the product, chewiness - the energy required for product fragmentation during chewing, and resilience (immediate elasticity) - the ability to return the product to the form of the initial state after the first compression (Surówka, 2002).

The chemical composition included:

- $\quad$ Protein content $(\mathrm{N} \times 6.25)$, crude fat, ash and total dietary fibre according to AOAC methods (2006);

- The content of macro-and micronutrients by atomic emission spectrometer with inductively coupled argon plasma ICP- AES: IY 238 ULTRAC Jobin-Ivon (France) according to EN - 14084.

Presented results are given as mean of at least two replicates. They were subjected to one-way analysis of variance (ANOVA) using Statistica 8.0 software program. The significance of differences was assessed by Duncan test at $\alpha=$ 0.05 .

\section{RESULTS AND DISCUSSION}

In previous studies on the possible application of germs in baking, it was shown their adverse effect on water absorption of flour, and on the mechanical properties of the dough, the volume and the quality of resulting bread (Gasiorowski, 2005; Kawka, 2009 b).

With the germs implementation, some modifications to technological process were suggested, in order to ensure bread quality. Also in previous studies it was observed, that bread manufactured with the use of fermented leaven (prepared from germs, yeasts and water), no detrimental effect of germs addition on dough properties was observed in case the leaven was fermented for at least 6 hours in order to destroy glutathione (Gasiorowski, 2005).

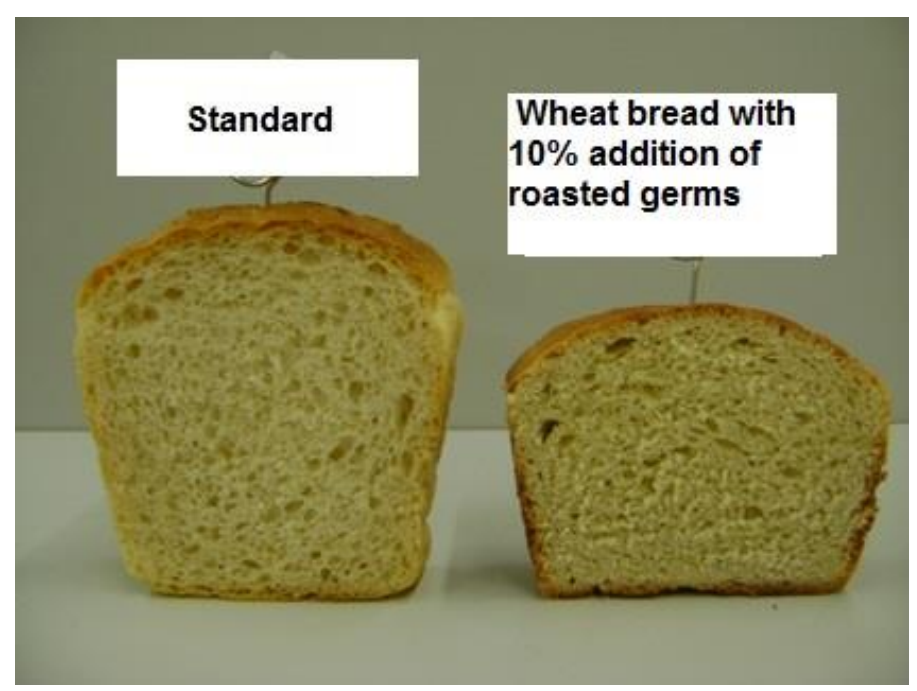

Figure 1 Wheat bread: standard (left) and with $10 \%$ roasted germs addition (right)

Before an attempt of bread supplementation with grounded germs took place, a flour water absorption analysis was conducted in Brabender Farinograph. Samples of flour type 650, and the same flour with addition of germs (calculated on flour basis) were analyzed. Such water absorption was $59.5 \%$ for wheat flour, and slightly lower $-58.4 \%$ for flour-germs composite, that confirmed the results of other authors (Kawka and Flaczyk, 2000; Gasiorowski, 2005).

Wheat breads prepared by direct method with addition of grounded roasted germs, regardless of hook rotation speed, were characterized by significantly lower volume in comparison to standard bread (Table 2, Figure 1) at comparable crumb moisture content (Table 2).

The adverse effect of the germs addition on bread volume was previously documented, and basing on multilateral studies, it was found that the negatively acting factor was a glutathione - tripeptide consisting of glutamic acid, cysteine and glycine. It is a co-enzyme responsible for cell constant redox potential. Due to the presence of a thiol group (derived from cysteine) is readily dehydrogenated and, changing its form from reduced in to oxidized form [thiol groups ( $\mathrm{SH}$ ) are oxidize in to the disulfide (-S-S)]. Previous studies shown, that the natural low content of glutathione in the wheat flour does not affect the properties of the gluten, and thereby it is baking properties (Li et al., 2004). In contrast, increased level of oxidized form of glutathione can block the free - $\mathrm{SH}$ group of glutenin, which hinders the formation of normal gluten structure, and negatively affects the rheological properties of the dough (Li et al., 2004). 
Table 2 Quality of wheat bread prepared without and with addition of stabilized wheat germ

\begin{tabular}{|c|c|c|c|c|c|c|}
\hline \multicolumn{2}{|c|}{ Type of bread } & $\begin{array}{l}\text { Standard } \\
\text { bread }\end{array}$ & $\begin{array}{l}\text { Bread with } \\
\text { addition of germs }\end{array}$ & $10 \%$ & $\begin{array}{lcr}\begin{array}{l}\text { Bread } \\
\text { addition } \\
\text { germs }\end{array} & \begin{array}{c}\text { with } \\
\text { of }\end{array} & \begin{array}{r}10 \% \\
\text { roasted }\end{array} \\
\end{array}$ & $\begin{array}{lrr}\text { Bread } & \text { prepared } & \text { with } \\
10 \% \text { addition } & \text { of } \\
\text { leaven } & & \\
\end{array}$ \\
\hline \multicolumn{2}{|c|}{ Mass of bread (after cooling) $[\mathrm{g}]$} & $213 a^{*}$ & $221 \mathrm{~b}$ & & $222 \mathrm{~b}$ & $221 \mathrm{~b}$ \\
\hline \multicolumn{2}{|c|}{ Bread volume $\left[\mathrm{cm}^{3}\right]$} & $742 \mathrm{c}$ & $510 \mathrm{a}$ & & $500 \mathrm{a}$ & $665 \mathrm{~b}$ \\
\hline \multicolumn{2}{|c|}{ Bread yield [\%] } & $139,1 \mathrm{a}$ & $142,5 \mathrm{~b}$ & & $143,3 \mathrm{~b}$ & $147,9 \mathrm{~b}$ \\
\hline \multicolumn{2}{|c|}{$\begin{array}{l}\text { Total baking loss } \\
{[\%]}\end{array}$} & $15,2 \mathrm{~b}$ & $11,9 \mathrm{a}$ & & $11,4 \mathrm{a}$ & $11,8 \mathrm{a}$ \\
\hline \multicolumn{2}{|c|}{ Bread moisture content [\%] } & $43,7 \mathrm{a}$ & $43,2 \mathrm{a}$ & & $42,8 \mathrm{a}$ & $43,5 \mathrm{a}$ \\
\hline \multirow[b]{2}{*}{$\begin{array}{l}\text { Organoleptic } \\
\text { assessment }\end{array}$} & Total score & 38 & 31 & & 26 & 38 \\
\hline & $\begin{array}{l}\text { Quality } \\
\text { grade/class }\end{array}$ & I & II & & III & $\mathrm{I}$ \\
\hline
\end{tabular}

* The values in the rows marked with different letters differ significantly at a significance level of $\alpha=0,05$

In order to inactivate a glutathione a dough was prepared with a share of fermented leaven from germs, yeast, sugar and water in the amounts as previously described, and with the addition of $5 \%$ vital wheat gluten. Bread obtained from such dough was characterized by well developed loaves, and loaves volume was only slightly, but significantly smaller than the standard bread volume, and by slightly darker fine-porous crumbs (Table 2, Figure 2)

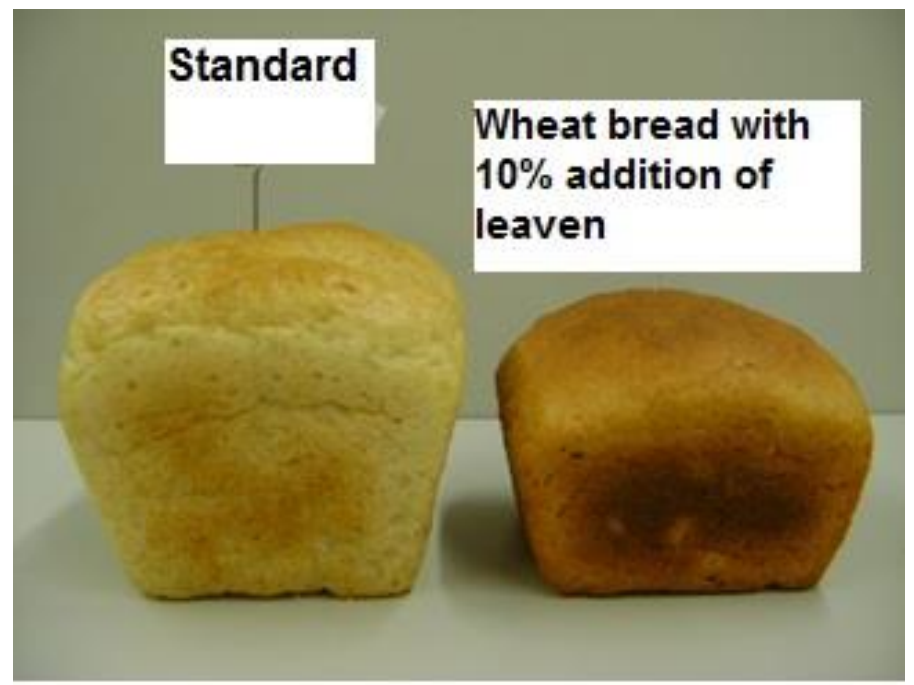

Figure 2 Wheat bread: standard (left), and with $10 \%$ addition of leaven

The results of organoleptic assessment of this bread was identical as a standard bread, because both breads were scored the same amount of points and were classified by the evaluation panel to the first grade. In contrast other wheat breads baked by the direct method obtained a very low consumer acceptance (second and third grade - Table 2), and for that reason their chemical composition was not analysed.

The aging of wheat bread supplemented with germs (both at day of baking, and during 3 consecutive days of storage) was monitored by changes in moisture content and texture of the crumb. As it can be concluded from the data presented in Figure 3 crumb moisture decreased over time of storage, but these changes in all evaluated breads were comparable and not significantly different (Figure 1). However, significant differences were determined in the bread crumb hardness on the day of baking (Table 3). The lowest hardness was observed in standard bread, and slightly higher but statistically significantly, in crumb of bread leavened with fermented germs. Other breads on day of baking were already characterized by about three times higher hardness of the crumb than standard one. These differences remained throughout the whole storage period (Table 3 ).

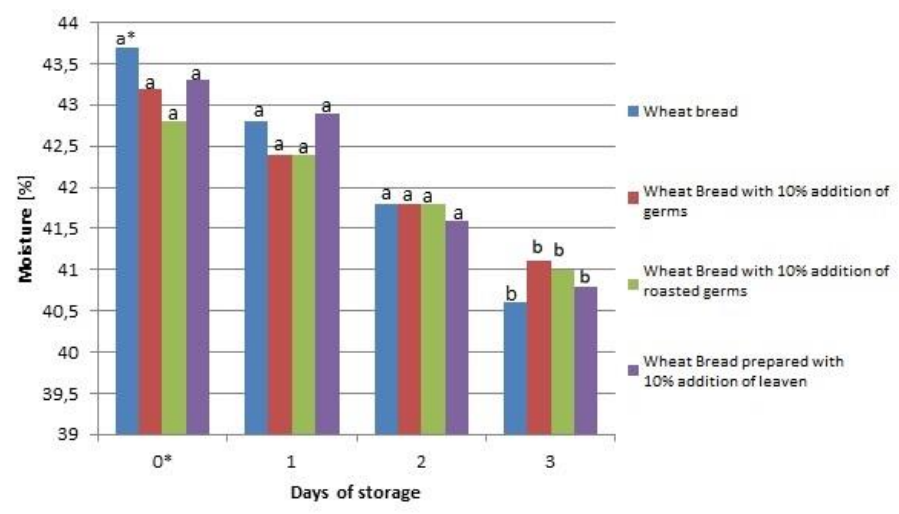

Figure 3 Changes in moisture of wheat bread crumb during storage $(0$ - day of baking, 1- first day after baking, 2-second day after baking, 3-third day after baking)

*The values in the columns marked with different letters differ significantly at a significance level of $\alpha=0.05$

The evaluation of nutrients in the wheat bread prepared on fermented germs leaven showed a significant increase in the content of dietary fibre (both insoluble and soluble fraction) and protein in germs supplanted bread, compared to the standard one (Table 4). Particular emphasis should be given to increase in protein content (about $6 \% \mathrm{dm}$ ) mainly due to the presence of germs, but also vital gluten.

Table 4 The chemical composition of standard and germs supplemented wheat breads

\begin{tabular}{lllll}
\hline Type of bread & $\begin{array}{l}\text { Protein } \\
{[\% \mathbf{d m}]}\end{array}$ & $\begin{array}{l}\text { Dietary fibre } \\
\text { [\% dm] } \\
\text { Insoluble } \\
\text { fraction }\end{array}$ & $\begin{array}{l}\text { Soluble } \\
\text { fraction }\end{array}$ & $\begin{array}{l}\text { Total } \\
\text { fibre }\end{array}$ \\
\hline Standard & $13,36 \mathrm{a}^{*}$ & $4,62 \mathrm{a}$ & $1,46 \mathrm{a}$ & $6,09 \mathrm{a}$ \\
\hline $\begin{array}{l}\text { Bread } \\
\text { supplemented } \\
\text { with germs } \\
\text { based leaven }\end{array}$ & $19,86 \mathrm{~b}$ & $5,88 \mathrm{~b}$ & $2,24 \mathrm{~b}$ & $8,12 \mathrm{~b}$ \\
\hline
\end{tabular}

* The values in the columns marked with different letters differ significantly at a significance level of $\alpha=0.05$

Wheat germs are a recognized source of mineral compounds (Gasiorowski, 2004 c), that was documented by the content of selected macro-and micronutrients identified in the examined wheat breads (Figure 4 and 5). With the exception of $\mathrm{Mg}$, and $\mathrm{Ca}$ contents of all minerals identified in breads containing germs were significantly increased, with respect to the standard bread.

Based on these results, it appears that further research on the possible use of wheat germ in wheat bread supplementation should be continued. Perhaps, the other modifications of technological process and additives (except gluten) would improve the consumer attractiveness of such breads with at least $10 \%$ germs addition, which guarantees a distinct improvement in the nutritional value of wheat flour breads. 
Table 3 The texture parameters of bread crumb

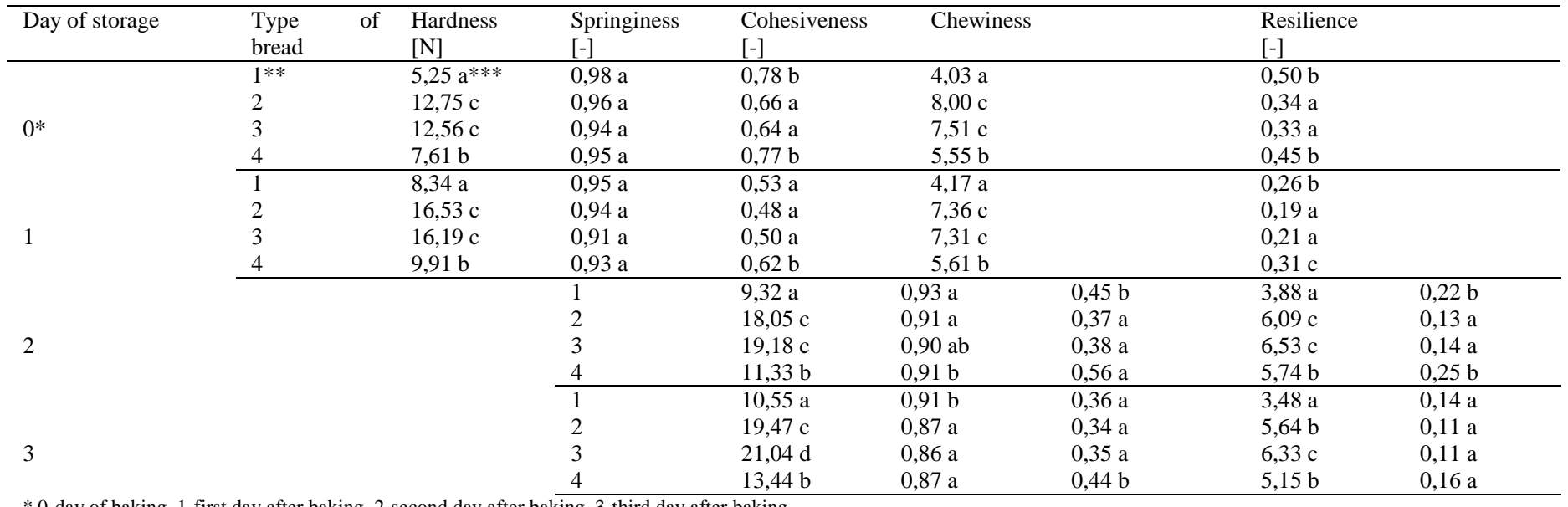

* 0-day of baking, 1-first day after baking, 2-second day after baking, 3-third day after baking

** 1-wheat bread standard, 2 -wheat bread with $10 \%$ addition of stabilized wheat germ, 3 -wheat bread with $10 \%$ addition of roasted stabilized wheat germ, 4 -wheat bread prepared with $10 \%$ addition of stabilized wheat germ leaven

*** The values in the column marked with different letters differ significantly at a significance level of $\alpha=0.05$

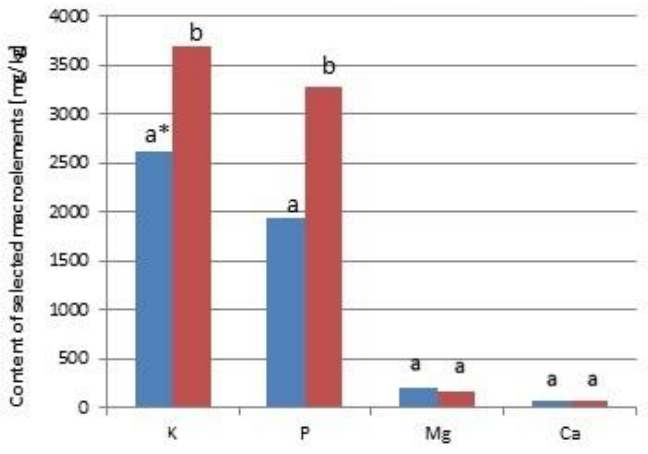

Wheat Bread

Wheat Bread prepared with $10 \%$ addition of leaven

Figure 4 The content of selected macroelements in wheat breads *The values on the columns marked with different letters differ significantly at a significance level of $\alpha=0.05$

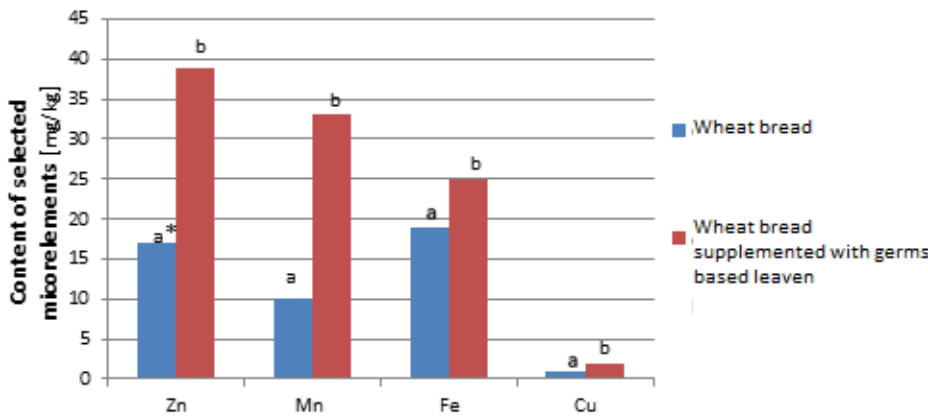

Figure 5 The content of selected microelements

*The values on the columns marked with different letters differ significantly at a significance level of $\alpha=0.05$

\section{CONCLUSION}

Single phase, direct method of dough preparation supplemented with grounded, stabilized wheat germs (in amount of $10 \%$ wheat flour weight) is not suitable for baking of such bread. The use of wheat germs in the form of leaven, after 24 hours of fermentation allowed to obtain bread with fair volume and textural properties, worth to be recommended to a wider scale production. The highest consumer acceptance received standard wheat bread (no germs added) and wheat bread leavened with a $10 \%$ share of stabilized wheat germs and $5 \%$ addition of vital wheat gluten, which were classified top class. Breads supplemented with germs in the form of fermented leaven were characterized by double the protein content and a significantly higher content of dietary fiber as compared to the standard bread. Analysis of selected minerals showed significant differences in the contents of $\mathrm{K}, \mathrm{P}, \mathrm{Zn}, \mathrm{Mn}, \mathrm{Cu}, \mathrm{Fe}$, in favor of germs supplemented bread.

\section{REFERENCES}

AOAC. 2006. Official methods of analysis 18thed. Gaithersburg. Association of Official Analytical Chemists International

FORTUNA, T. (Red) 2012. Podstawy analizy i oceny jakości żywności. Skrypt do ćwiczeń. Wydawnictwo Uniwersytetu Rolniczego w Krakowie.

GĄSIOROWSKI, H., KAWKA, A., KIRYLUK, J., RATAJCZAK, P. 1994. Surowce i przetwory o charakterze profilaktycznym i ich wykorzystanie, w: Stan aktualny i perspektywy rozwoju wybranych dziedzin przetwórstwa żywności pod red. J. R. Warchalewski. Seminarium z cyklu: Związi Nauki z Praktyka, POLAGRA 94. Wyd. PTTŻ - Oddział Wlkp. s. 167 -203.

GĄSIOROWSKI, H. 2004 a. Zarodki pszenne. Budowa anatomiczna, metody pozyskiwania. Cz. 1. Przeg. Zboż. Mlyn. 49, 8, 12 - 13 .

GĄSIOROWSKI, H. 2004 b. Zarodki pszenne. Zarodki handlowe. Cz. 3. Przeg. Zboż. Mlyn. 49, 11, $13-16$.

GASIOROWSKI, H. 2004 c. Zarodki pszenne. Zarodki handlowe. Skład chemiczny - ciąg dalszy. Cz. 4. Przeg. Zboż Mlyn. 49, 12, 7 - 9.

GASIOROWSKI, H. 2005 . Zarodki pszenne. Zarodki w dietetyce i inne sposoby ich wykorzystania. Cz. 9. Przeg. Zboż. Młyn. 50, 6, 12-12.

JAKUBCZYK, T., HABER, T. (Red.) 1981. Analiza zbóż i przetworów zbożowych. Skrypt $S G G W$. Warszawa.

JANKOWSKI, S. 1981. Zarys technologii młynarstwa i kaszarstwa. WNT, Warszawa.

KAWKA, A. 2009 a. Przetwory zbożowe - aspekty wzbogacania wartości odżywczej. Przeg. Zboż. Młyn. 54, 10, 2 - 7.

KAWKA, A. 2009 b. Możliwość wzbogacania wartości odżywczych, dietetycznych i funkcjonalnych pieczywa, w: Żywność wzbogacana i nutraceutyki. Wyd. PTTŻ - Oddział Małopolski, Kraków

KAWKA, A., FLACZEK, E. 2000. Dodatki technologiczne wzbogacające pieczywo. Przeg. Piek. i Cuk. 48, 5, 8.

MARCINIAK, A., OBUCHOWSKI W. 2007. Prozdrowotne właściwości produktów zbożowych. Przeg. Piek. i Cuk. 55, $12-15.63$.

LI, Y, WEI, G., CHEN, J. 2004. Glutathione: a review on biotechnological production. Appl Microbiol Biotechnol. 66, 233-242.

PN-A-74108:1996. Pieczywo. Metody badan.

SURÓWKA, K., 2002. Tekstura żywności i metody jej badania. Przem. Spoż. 10, 12-17.

ZIELIŃSKI, H., KOZŁOWSKA, H., LEWCZUK, B. 2001b. Bioactive compounds in de cereal grains before and after hydrothermal processing. Innovative Food Science and Emerging Technologies, 2, 159 - 169.

ZIELINSKI, H., KOZŁOWSKA H. 2000. Antioxidant activity and total phenolics in selected cereal grains and their different morphological fractions. Journal of Agricultural and Food Chemistry 48, 2008 - 2016. 